\title{
Eestikeelne usuõpetus (katehhees) õigeusu kirikus ${ }^{1}$
}

\begin{abstract}
Liina Eek
Teesid: Artikkel keskendub eestikeelsele katehheesile (usuõpetusele) Eesti õigeusu kirikutes - Eesti Apostlik-Õigeusu Kirikus ja Moskva Patriarhaadi Eesti Ôigeusu kirikus (edaspidi EAÕK ja MPEÕK). Lisaks uuritakse, kui vajalikuks peavad eestikeelsed õigeusu vaimulikud usuõpetuse andmist kogudustes, mida peetakse kirikuga liitumisel minimaalselt vajalikeks teadmisteks ning millal peaks katehheesi läbi viima. Antakse ülevaade tänapäevasest eestikeelsest katehheesi andmisest õigeusu kirikus ning kirjeldatakse religioonisotsioloogilise uurimuse käigus kogutud intervjuude põhjal vaimulike erinevaid seisukohti. Lõpuks tuuakse välja üldised suundumused ja kitsaskohad eestikeelse katehheesi andmisel.
\end{abstract}

Märksõnad: EAÕK, eestikeelne usuõpetus kirikus, katehhees, MPEÕK, õigeusk

\section{Sissejuhatus}

Õigeusu kirikus läbib inimene enne kogudusega liitumist katehheesi. Katehheesi ehk kirikus antavat usuõpetust ja usulist kasvatust peetakse kõige paremaks usulise hariduse andmise viisiks ${ }^{2}$, eriti endistes Nõukogude Liidu maades, kus usulise hariduse tase on madal ja põlvkondade-vaheline järjepidevus kadunud. Väidetavalt vajavad täiskasvanud tänapäeval katehheesi rohkem kui lapsed ${ }^{3}$ (Kozhuharov 2006: 56). Tänapäeval kestab katehhees õigeusu kiriku(te)s keskmiselt kuus kuud kuni aasta, mille jooksul kirikuga liituja ehk katehumeen osaleb teenistustel ning saab juhiseid kas vaimulikult või ilmikust õpetajalt ${ }^{4}$ (McDowell 2014: 88).

Katehheesil on õigeusu kirikus suur roll. Eestikeelse usuõpetuse andmine ja sellega seonduvalt ka vaimulike haridus on olnud pikka aega kiriku prioriteet. Esimesed eestikeelsed vaimulikud said oma hariduse 19. sajandi keskpaigast alates Riia viieklassilises vaimulikus koolis või Riia vaimulikus seminaris (Schvak 2011: 72). 1917. aastal Tartus toimunud piiskopkonna koosolekul arutati 
preestrite hariduse olulisust ja Tartu Ülikooli juurde õigeusu teaduskonna või iseseisva akadeemia asutamist, ${ }^{5}$ samas jõuti ka kokkuleppele, et kõikidel preestritel peab olema keskharidus (UE 1917: 343-344). Eesti Vabariigi algusaastail korraldati vaimulikke kursusi ning avati Tartu Ülikooli õigeusu teaduskond ja Petseri vaimulik seminar, millest viimases õpetati ka didaktikat (Schvak 2011: 82). 1919. aastal võeti kiriku täiskogu koosolekul vastu veel mitmeid resolutsioone usuõpetuse kohta, muu hulgas märgiti, et usuõpetamise "tavas ja viisis" tuleb läbi viia põhjalik reform ning soovitati usu või konfessiooni õpetus selle kitsamas mõttes viia koolist välja, kirikute ja nende esindajate ülesandeks (UE 1919: 46). Seega kanti vabariigi algusaegadel katehheesi põhiline raskuskese kirikule. 1940. aastal lõpetas okupatsioon nii õigeusu teaduskonna ja Petseri seminari tegevuse kui ka üldse igasuguse katehheetilise töö. Sellest ajast kuni taasiseseisvumiseni ei saa katehheesist rääkida, sest seda ei toimunud.

Praegu valitseb EAÕKs suundumus, kus püütakse anda suuremat rolli perekonnale ja rõhutatakse perekonna kui koduse kiriku pedagoogiliste pingutuste vajalikkust, eriti noorte ja murdeealiste puhul (Metropoliit Stefanus 2013: 56). MPEÕK seisukohad on rohkem seotud Venemaa Õigeusu Kiriku (edaspidi VÕK) otsuste ja arvamustega. ${ }^{6}$ VÕKi Moskva ja kogu Venemaa patriarh Aleksius II hindas kõrgelt usulise hariduse andmist ja leidis, et sellel on kirikuelus fundamentaalne roll (Wallace 2006: 150). Seda seisukohta on praegune VÕKi patriarh Kirillus edasi arendanud, muutes katehheesi kohustuslikuks (vt nt Prekup 2012: 82). VÕKi Pühima Sinodi usuõpetuse ja katehheesi osakond (SOROK) koostas 2011. aastal dokumendi usuõpetuse ja katehheetilise diakoonia kohta õigeusu kirikus. ${ }^{7}$ Peale vaimulike haridust käsitleva osa räägitakse selles ka katehheesi kohustuslikkusest, kusjuures katehumeenidena määratletakse selles dokumendis üle 12aastaseid noori ja täiskasvanuid. Vastavalt VÕKi Pühima Sinodi otsusele peab kirikuga liituda soovija, sh ka need, kes soovivad oma last ristida lasta, vähemalt paar korda katehheesis käima ning kogudused peavad tagama katehheesi andmise. Dokumendis ei räägita küll päris täpselt, kuidas ja mis kujul peaks katehhees toimuma, kuid SOROK julgustab iga kogudust looma oma katehheesi kooli, pidades kooli all silmas katehheesi andmise erinevaid vorme - klubilisi üritusi, kohtumisi, ühiseid söömaaegu, palverännakuid, ühiseid üritusi, õpperühmi, kus ainult ei õpetata doktriine, vaid elatakse koos õigeusus selle parima traditsiooni valguses (Kozhuharov 2006). Seda soovitust järgivad ka MPEÕK vaimulikud Eestis ning tavaliselt soovitavad preestrid ristitavate laste vanematel ja vaderitel tulla enne ristimist liturgiale ja vestelda preestriga (Paert \& Schvak 2015: 187).

EAÕKs ei ole usuõpetuse andmine kogudustes kohustuslik, vaid sõltub koguduse ja/või preestri vajadustest ja võimalustest. EAÕK Tallinna ja kogu Eesti 
metropoliit Stefanus peab noortetööd kogudustes ning usuõpetuse andmist keskseks küsimuseks (vt nt tema sõnavõtt 2015. aastal EAÕK täiskogul; metropoliit Stefanus 2015: 3-5). 2015. aasta kevadel alustati 1999. aastal loodud EAÕK Noorte Liidu töö ümber korraldamist (Tölpt 2015: 9). Selle töö eestvedaja, preester Aabraham Tölpt rõhutab, et preester ei peaks ristima "inimesi tänavalt", vaid ristimisele ja kirikusse vastuvõtmisele peaks eelnema kohustuslik katehhees. See on praeguseni veel soovitus, mitte kohustus.

Usuõpetuse andmine on kiriku põhitegevusena toodud nii EAÕK kui ka MPEÕK põhikirjas. MPEÕK põhikirjas on lausa eraldi peatükk "Usuõpetuse ja kanoonilise korralduse alused ning usulised talitused", EAÕKs on sarnase sisuga sätted lülitatud üldsätete alla. Põhimõttelisi erinevusi kahe kiriku põhikirjade lähenemisel (usu)õpetusele pole, ning kumbki ei käsitle oma põhikirjas eraldi katehheesi andmist ${ }^{8}$.

Katehheesi eestikeelses õigeusu kirikus ja preestrite arvamust selle vajalikkuse kohta pole kuigi palju uuritud. Seda, kuidas usuõpetust antakse tänapäeva EAÕKs, on käsitlenud EELK Usuteaduse Instituudis 2011. aastal kaitstud magistritöös "Nüüdisaja usuõpetustöö EAÕK kogudustes" Helen Kooviste, kes küsitles EAÕK vaimulikke, et teada saada nende meelestatust ja valmidust usuõpetustöö edendamiseks. MPEÕK eestikeelse usuõpetuse andmise kohta ei suutnud ma leida ühtegi uurimust.

\section{Katehhees EAÕKs}

Helen Kooviste esindab oma eelpool viidatud magistritöös ametlikku EAÕK lähenemist ja määratleb katehheesi kui usuõpetust, mis toimub enne kirikuga liitumist. Katehhees sisaldab üldist õpetust kristlikust usust ning nende õigeusu teadmiste edastamist, mis on vajalikud kogudusega liitumiseks ristimise ja/ või salvimise vahendusel. EAÕKs viib katehheesi tavaliselt läbi preester ning see toimub individuaalse vestlusena, mille käigus preester tutvustab suuliselt õigeusu kiriku õpetust, soovitab lugemiseks kirjandust jne. Vestluskordi võib olla üks või rohkem. Katehheesitööd on tehtud ka väikestes 3-5liikmelistes rühmades (Kooviste 2011: 8).

Osa katehheesitööd tehakse pühapäevakoolides. Eesti Kirikute Nõukogu annab oma kodulehel ülevaate tänapäeva pühapäevakoolidest, ${ }^{9}$ kus on kirjeldatud ka EAÕK lähenemine. EAÕK selgitab, et vähest lastetööd kompenseerib kristlik kasvatus peres ja koguduses. ${ }^{10}$ Alates Eesti Õigeusu Noorte Liidu loomisest 1999. aastal on korraldatud laste- ja perelaagreid, lastelaagreid korraldavad lisaks ka mõned kogudused. 
EAÕK ametlikul kodulehel ${ }^{11}$ on spetsiaalne lastele mõeldud nurgake ning leidub ka viiteid katehheetilistele väljaannetele. Lastenurgakesest leiab muu hulgas eesti- ja venekeelseid lihtsaid katehheetilisi kirjutisi. EAÕK annab välja ajalehte Metropoolia ${ }^{12}$ igas lehes leidub katehheetilisi kirjutisi ning lastele mõeldud osa, mis on lingitav ka EAÕK kodulehe lastenurgast. Kuna tegu on tasuta jagatava ajalehega, on see koguduseliikmetele kergesti kättesaadav ja loetav kirikuskäijate seas. Ilmub ajakiri Usk ja Elu, mille sisu peavad aga paljud koguduse liikmed liiga akadeemiliseks. ${ }^{13}$ EAÕK Pärnu ja Saare piiskopkond annab välja ajalehte Pantokraator, mille peamine sisu ongi katehheetilised materjalid. Palju katehheetilist kirjandust on välja andnud Eesti Õigeusu Noorte Liit. Peamiselt avaldab eestikeelset õigeusu-alast kirjandust EAÕK juures tegutsev Püha Platoni õigeusu teoloogia seminar, kus antakse regulaarselt välja ka katehheetilist kirjandust. Neist olulisimad, mida vaimulikud sagedasti katehumeenidele lugeda soovitavad, on piiskop Kallistos Ware raamat Õigeusu tee (2001) ning EAÕK metropoliit Stefanuse Pilguheit õigeusku (2011). Preestrid soovitavad sageli kogudusega liitujatele lugeda sarjas "Ajalugu ja teoloogia" ilmunud raamatuid. Teine sageli mainitud katehheetilisel eesmärgil kasutatav teos on Püha Porfiriose elu ja õpetused, mis ilmus aastal 2014 EAÕK kirjastuses.

\section{Eestikeelne katehhees MPEÕKs}

MPEÕK selgitav sõnaraamat avab katehheesi mõistet järgnevalt: "Katehhees ( $\mathrm{kr}$ katēchēsis) on hiljuti kiriku liikmeks saanud või ristimise sakramendiks valmistuvatele inimestele põhiliste õigeusu tõdede selgitamine."14

MPEÕK Sinodi juures tegutseb religiooni- ja usuõpetuse osakond, mille esimees on Narva ja Peipsiveere piiskop Laatsarus. Osakond teeb märkimisväärselt palju tööd katehheesi edendamiseks ja vastavasisulise kirjanduse levitamiseks. Osakonnal on õigeusu haridusest ka oma kodulehekülg, ${ }^{15}$ mis paraku on leitav vaid MPEÕK venekeelse kodulehe kaudu, eestikeelse lehekülje need leheküljed annavad veateate ("Vabandage, lehekülg ajutiselt ei tööta"). Venekeelne lehekülg sisaldab hulgaliselt katehheetilist materjali, infot suuremate koguduste pühapäevakoolide ja lastelaagrite jm ürituste kohta. ${ }^{16}$ Kirjeldatud on õppekavu, käimasolevaid tegevusi ja tulevikuplaane (nt luua täiskasvanute grupid, korraldatavad laagrid jne). Praegu korraldab enamik kogudusi nädalavahetustel või õhtuti spetsiaalseid katehheesikursusi täiskasvanutele (Paert \& Schvak 2015: 186). MPEÕK koduleheküljel ei ole andmeid kõikide koguduste kohta, vaid ainult suuremate ja aktiivsemate kohta. Kahjuks puuduvad sealt ka viited eestikeelsetele üritustele, kuigi mõned ürituste läbiviijad 
või pühapäevakooli õpetajad on eesti nimedega ja võiks eeldada, et mõned üritused toimuvad ka eesti keeles. Erandiks on siin Nõmme Ristija Johannese kogudus, kus on mainitud ka eestikeelseid gruppe: pühapäevakoolid toimuvad vaheldumisi eestikeelsetele ja venekeelsetele gruppidele.

MPEÕK annab välja kord kuus ilmuvat ajalehte Õigeusu Maailm (Mir Pravoslavija), kus leidub küll ka katehheetilist materjali, kuid ainult vene keeles. Oluline eestikeelset õigeusualast kirjandust välja andev kirjastus on MPEÕK juures tegutsev Püha Issidori Kirjastusselts. Siin tuleks eriti märkida 2005. aastal välja antud Õigeusu aluseid, mida paljud preestrid nii EAÕKs kui MPEÕKs katehumeenidele esimese raamatuna lugeda soovitavad. Selle raamatu olulisust rõhutasid mitmed intervjueeritud preestrid, soovitades seda kui raamatut, mida võiks lugeda inimene, kes õigeusust midagi ei tea, kuid soovib end õigeusu põhitõdedega kurssi viia.

\section{Materjal ja metoodika}

Originaalmaterjali kogusin aastatel 2012-2014 kahes Eesti õigeusu kirikus EAÕKs ja MPEÕKs - poolstruktureeritud intervjuude käigus suurema kvalitatiivse religioonisotsioloogilise uurimuse alaosana. Tulemused töötlesin sisualanüüsiga, kategoriseerides induktiivselt saadud vastused ning tehes nende alusel üldistused.

Intervjueerisin eesti keelt kõnelevaid vaimulikke. Eestis oli aastal 2014 (intervjuude tegemise ajal) EAÕKs 28 tegutsevat preestrit, kui välja arvata piiskopid ja preestrid, kes on välismaal või emeriteerunud (Kalender 2013: 87-89). Küsitlesin 17 preestrit (60\% EAÕKs tegutsevatest preestritest). MPEÕK eesti keelt kõnelevatest preestritest soostus minuga vestlema vaid üks, seega oli informante kokku 18. Preestrite vanus on intervjuudes märgitud 10aastase täpsusega, et tagada nende anonüümsus.

Uurisin preestrite suhtumist katehheesi vajalikkusesse ning lisaks küsisin, kuidas nad oma koguduses katehheesi läbi viivad. ${ }^{17}$ Analüüsi ei ole hõlmatud muid vaimulikke (diakone, piiskoppe), sest usuõpetuse korraldamine kogudustes ja uute kogudusega liituda soovijatega vestlemine on peamiselt preestrite ülesanne, diakonid ja piiskopid sellega üldjuhul ei tegele.

\section{Vaimulike suhtumine katehheesi vajalikkusesse}

Võttes aluseks eespool tsiteeritud MPEÕK selgitava sõnaraamatu, on katehhees "hiljuti kiriku liikmeks saanud või ristimise sakramendiks valmistuvatele 
inimestele põhiliste õigeusu tõdede selgitamine" (minu kursiiv). Nagu nähtub sellest määratlusest, ei ole üheselt kindlaks määratud, millal katehheesi läbi viima peab - kas enne või pärast kirikuga liitumist (ristimist ja/või salvimist, kui tullakse üle mõnest muust kristlikust konfessioonist ${ }^{18}$ ). Samamoodi tõlgendavad seda erinevalt ka preestrid, kel on lisaks ka erinevad arusaamad katehheesi põhjalikkusest ja vajalikkusest. Kõik intervjueeritud preestrid katehheesi ei korraldagi. Seda ei tehta erinevatel põhjustel - mõni ei näe selleks vajadust, mõnel pole selleks võimalusi (ruume, aega, puudub koguduse huvi), mõni on preester koguduses, kus katehheesi viivad läbi juba teised inimesed ja tema kaasamiseks puudub otsene vajadus.

Kohtasin erinevaid arvamusi alates sellest, et katehhees enne ristimist pole vajalik kuni selleni, et pikk ja põhjalik katehhees on ilmtingimata vajalik. Kohtasin üht preestrit, kes esindas arvamust, et ristida võib kõiki soovijaid, ning ütles, et kui ristida laskmine on inimese soov, siis on preestri kohustus seda täita ilma omapoolseid tingimusi või küsimusi esitamata.

Ei tee mingit katehheesi neile, kes soovivad lasta end ristida, selle pärast, et... mis ma pean tegema? Inimene tuleb siia, on hommikul vara [---] platsis, ütleb, et ta tahab lasta end ristida. Mis ma ütlen talle siis, et tule kahe aasta pärast või? Miks see peaks mind huvitama [motivatsioon, miks inimene laseb end ristida]? Mind see absoluutselt ei huvita, miks ma peaksin teise inimese ellu sü̈̈vima, tema isiklikke motiive, tema isiklikke asju [uurima]? [---] Ristimisega me paneme inimesele aluse, kui ta [seda] juba tahab, siis palun väga, miks mitte! See on tema enda vaba tahe. Mina ei saa teda keelata, et ei tohi. See on mu kohus teda ristida (40-50 a).

Sellist suhtumist kohtasin väga harva, kuigi paar preestrit möönsid, et on vahel ristinud inimesi ilma eelneva usuõpetuse või vestluseta.

Olen ka nii ristinud, et helistab ja tuleb kohale. Ei saagi enne kokku, küsin lihtsalt, et kas usub, ta ju ikka usub. Tänapäeval peaks olema ristimine enne ja siis katehhees, mitte katehhees enne ristimist (40-50 a).

Enamik küsitletud preestritest tahab enne ristimist inimesega vähemalt vestelda, nad soovitavad neile kirjandust ning mõned korrad jumalateenistusel ära käia, et inimene saaks selgema pildi, millega ta liituda soovib.

Enne ristimist ikka vestleme, päris nii ei ole, et astud uksest sisse ja kohe ristime. Annan lugeda ka ja soovitan jumalateenistusel käia vähemalt korra, et vaadata ja hingata seda vaimsust, käigu ära ja tulgu siis tagasi (40-50 a). 
Sõltub inimesest. Asi algab teenistustel käimisest, mitte lugemisest. Kui teenistus eemale tõukab, pole õige koht, ja mul ei ole mingit mõtet hakata katehheesi tegema (60-70 a).

Suur osa preestritest tahab enne ristimist teada saada kirikuga liitumise motiive. Nagu eespool kirjutatust selgus, ei pea mõned üksikud preestrid selle selgitamist vajalikuks, teised jälle leiavad, et motiiv on oluline.

Enne ristimist räägin need asjad läbi, et miks ta tahab seda teha. Kas see on enda südame tunne, mingi emotsioon või keegi lihtsalt ütles, et kui ära ristid, siis saad kõikidest muredest lahti. Need asjad tuleb enne selgeks rääkida (50-60 a).

Mitmed preestrid püüavad selgeks teha, kas inimene on sisemiselt valmis kirikuga liituma.

Iga inimest tuleb vaadata kui erijuhtumit. Kui ma näen, et inimene on valmis, ta januneb seda, tal on seda vaja, ta on ära tundnud, et tal on siin hea, siis miks ma peaks teda piinama? (40-50 a)

Kindla peale [enne kirikuga liitumist] suhtleme päris mitmeid kordi. See ei ole mingi asja omandamine, suhtlemine on päris pikk, aga ma ei eelda, et inimene oleks usuteadlane, loeb palveid peast, ma eeldan, et inimese süda ihkab seda ja siis me vaatame veel üle, et kas sa ikka tead, mida sa teed. Kui ei ole kindel, siis on parem veel oodata. Vaimsed energiad on reaalsed, kui sa ei ole selleks [ristimiseks] valmis, siis hakkab see sind rebima ja teeb palju kurja (50-60 a).

Mõne inimese soov kirikuga liituda on ajendatud vajadusest saada kellegi ristivanemaks. On preestreid, kes sellist põhjendust ei aktsepteeri ja leiavad, et kirikuga liitumiseks on vaja enamat, midagi olemuslikumat, sisemist soovi.

Liituda soovijatele annan lugeda ja küsin, mis on nende motiiv. Kui nende ainus motiv on see, et nad peavad saama kellegi ristiisaks või ristiemaks, siis nii see ei lähe. Inimesel peab olema motiv, ma ei saa inimeste hingeondsusega mängida (40-50 a).

Kui motiiv on ristivanemaks saamine, kuid katehumeenil pole mingeidki teadmisi ristiusust, siis soovitatakse enne ristida laskmist end põhiliste usutõdedega kurssi viia, sest ristivanemaks olemine tähendab vastutust oma ristilapse ees, vaimulikku eeskuju ja usulise kasvatuse andmist ning seda ei saa teha, kui ise asjast midagi ei tea. 
Kui inimene tuleb minu juurde selle pärast, et saada ristiemaks või ristiisaks - see asi ei käi niimoodi [siis ma teda ei risti]. Ma alustan temaga suhtlust, ma ei risti teda kohe ära, seal peab olema mingi sisemine pool $k a$ [mitte ainult väline]. Ristiemaks või -isaks olemine ei ole niisama, see on vastutus. Ma ei saa lubada inimesel võtta vastutust, kui ta ei saa aru, mille eest ta vastutust võtab. Enne ristimist tuleb anda mingisugune baas, mingi arusaamine, tegelik elu hakkab siis, kui me oleme ristitud, siis avanevad uksed. Inimest on vaja enne [ristimist] häälestada, natuke ette valmistada. Sisemine valmisolek peab olema (40-50 a).

Lisaks ristida laskmise motiivide selgitamisele seavad mõned preestrid teatud miinimumnõuded, millele inimene peab vastama, kui ta soovib kirikuga liituda. Preestrid on üldjuhul realistid ja saavad aru, et tänapäeva inimene ei lase endale kuigi palju ettekirjutusi teha, kui neile liiga palju nõudmisi esitada, lähevad nad lihtsalt minema. Üldine suundumus on selline, et preestrid sooviksid, et liituja oskaks peast usutunnistust ning saaks ka üldjoontes aru, millest usutunnistus räägib.

[...] ma nõuan ainult, et usutunnistus peab peas olema. Ma kohtun nendega, räägin, näitan katehheetilisi [...] filme, 15-20 minutit, kiriku ajaloost, kirikust, salasuste kohta jne. [---] Kui sa hakkad neile midagi õpetama, siis nad enam ei tule. Mis teha, inimesed on sellised. [---] Aga kui ma annan midagi lugeda ja hakkan midagi väga innukalt rääkima, siis need ei tule tagasi ja kaovad koos raamatutega ära. Nõudmised peavad olema minimaalsed, ei ole mõtet laadida neid teadmisi, tänapäeva inimesel on niivõrd kiire, inimesed on nii uhked ja kõrgid, kui sa hakkad neile suruma mingit oma asja, siis nad ei võta seda vastu (30-40 a).

Isegi usutunnistuse peast teadmist ei peeta möödapäästmatult vajalikuks, vaid ka sellesse suhtutakse mõnel juhul leebelt.

Kui inimene pole ristitud, tuleb ta ristida. Enne ristimist on meil vestlus. Ma alati küsin, miks ta tahab lasta end ristida. Kui ma näen, kui ta ütleb, et see on pere traditsioon, siis ma küsin igaks juhuks, mida ta teab üldse õigeusu kohta ja no siis tal peab see usutunnistus [peas olema], aga tegelikult ei pea ka peas olema, ma ei nõua. Oleks hea kui oleks, aga... Kui ma näen, et inimene mitte midagi ei tea, siis annan talle raamatuid, lepime kokku, ta võib küsida, ja siis on vestlus, kus ma võin tema käest küsida küsimused [õigeusu kohta]. [Algteadmised peaksid olema], niisama ma ei risti (40-50 a). 
Vaimulikud eeldavad, et kui inimene juba usutunnistust teab, siis ta saab sellest ka aru ja nõustub seal öelduga.

Kui täiskasvanud inimene tahab ristitud või salvitud saada, siis ta peab aru saama ja nõus olema sellega [millega ta liitub]. Ta ei saa usutunnistust lugeda formaalselt, ta peab seda uskuma, muidu ta ei saa astuda osadusse (40-50 a).

Sealt see usutunnistus ju tulebki, et inimene enne ristimist midagi teab ja usub. Mingi usk ja teadmine peab olema, see on eeldus, et tulla ristimisele. Kui sa salgad ära saatana, siis järelikult pead sa midagi ka saatanast teadma. Kas sa ühendad end Kristusega? Sa pead ikka teadma, kes on Kristus. Kas sa usud temasse kui kuningasse? Jah, usun. Aga kuningat pole ju olemas, mis see siis tähendab? Peab natuke läbi mõtlema enne (40-50 a).

Preestril on vastutus, ta peab tõesti veendunud olema, et inimene usub tõesti seda usutunnistust ja tahab olla Kristuse ihu liige. Igaühega on see erinev. Mõnega läheb kiiresti. Enne vestlen nendega, sõltuvalt inimesest, kui mitu korda. Ühtset retsepti pole. [---] Mul on peas mingid asjad, mida ma räägin, ajaloost ja kirikust, ja kõige olulisem, käime usutunnistuse punkt punktilt läbi. Usutunnistust käib läbi tükk aega, mitu korda tuleb kohtuda ja sellest rääkida (40-50 a).

Ka selles osas on mõned preestrid leebemad ja leiavad, et inimene võib liituda kirikuga, öelda usutunnistuse formaalselt ning alles pärast ristimist algab tema usuline areng ja ta saabki alles hiljem aru, mida ta on kinnitanud end uskuvat.

Minu arusaamine on, et kui inimene tuleb kirikusse ja tahab saada ristitud, ja loeb usutunnistust, siis ma ei näe põhjust, miks ma peaks kahtlema, et sa ütlesid nü̈̈d seda, kuidas sellega nüüd täpselt on, mida sa mõtled või tunned. Loomulikult, kui ma seda asja kõrvalt vaatan, siis ma saan aru, et alati ei aduta, millest see usutunnistus räägib, aga teisest küljest [ei saa me ka öelda, et] kui sa pole kuigivõrdki sellest aru saanud, millest seal [usutunnistuses] räägitakse, siis me sind ei risti. Võib-olla seda tõuget ongi vaja [ristimist], võibolla kukub see seeme viljakasse mulda, me ei tea ju seda (50-60 a).

Mõnel preestril on kõrgemad miinimumnõuded kui usutunnistuse teadmine, nad nõuavad ka muid algteadmisi, mida jagatakse kas vestluste või kirjanduse kaudu, jumalateenistusel katehheetiliste loengute või jutluste kaudu. 
Ma suhtlen inimestega nii palju, kui nad on altid vastu võtma. Ma ei ole teinud sellest kohustust. On teatud esmased raamatukesed, nende põhjal toimub see vestlus ja see $n$-ö vastuvõtmine ja tunnustamine. Seal on liturgiast teatud asjad, seal on sakramentidest, usutunnistusest teatud asjad. [---] Eesmärk on inimese vastuvõtmine kogudusse, nende miinimumide täitmine, mida kogudusse tulemine eeldab inimeselt ja sealt see liturgiline elu hakkabki teda kasvatama. Seal ta hakkabki õppima kõigepealt seisma, tee peal olema, liikuma selles suunas (40-50 a).

Oleneb inimesest. Meie koguduses ei ole katehheesitunde [---]. Meie koguduses on [enne ristimist] vestlus preestriga. See on kindlasti kohustuslik. Preester annab ka mingid ülesanded tavaliselt. [---] Vahel tulevad need, kes pole evangeeliumitki lugenud. Siis annan lugeda, apostlite kirjad, vähemalt üks evangeelium, palveraamatu peaks soetama, et harjutada hommiku-ja õhtupalveid, armulauapalveid. Kindlasti soovitan paar nädalat käia teenistustel. Mõnega rohkem räägime, mõni on rohkem küps (40-50 a).

Viimaks oli ka preestreid, kes leiavad, et katehhees on täiskasvanud kirikuga liitujatele kohustuslik ja vaid erandjuhtudel, nt kehva tervise puhul, tehakse selles vallas mööndusi.

Ilma katehheesita reeglina ei kipu ristima, kui just pole tegu väikelapsega. Reeglina lapsed vanuses 12-15 ristime katehheesita, eeldusel, et perekond on oigeusklik. [---] Väga individuaalne. Ideaalina näeks, et inimene on ristimiseks küps siis, kui ta on õppinud vaimuliku isaga sidet pidama ja kirikus käima. See on tema elu osa, on tekkinud sisuline side. Eesti elutempo juures on selle ideaalini väga raske jõuda (30-40 a).

Mitu preestrit leidis, et ristimise-eelne katehhees võib olla minimaalne, sest tegelik usuline areng algab alles pärast ristimist ja kõikidest asjadest isegi ei tohi enne ristimist rääkida.

Jeruusalemma Kirill [ütles, et] kõigest ei saagi enne ristimist rääkida. Sa ei saagi mõnest asjast aru saada. Jeruusalemma Kirillil [on] katehheesid, üle 20, ristimise eelsed ja selle järgsed, tunniajased loengud. Mõnele on rohkem vaja, mõnele vähem. [---] Paljud inimesed kaovad ära, neil on nii palju tegemisi. Oluline, et inimene saaks aru, et see on terve elu muutus, mitte dogmaatilised teadmised (30-40 a).

Alles peale salvimist, kui inimene hakkab käima armulaual, mingi aeg, võib-olla aasta läheb, enne kui ta hakkab üldse aru saama, mis tema 
ümber toimub, alles siis on vaja õppima hakata. Õppimine kestab kogu elu, oleneb, kuidas sellesse süveneda. Eesti kombe järgi arvatakse, et kui ta ära salvitakse, siis ongi kõik, tegelikult see nii ei ole. Peaks seda [õpinguid] jätkama (40-50 a).

Nagu eespool mainitud, ei ole vaimulike seas konsensust selles osas, kas katehheesi anda enne või pärast kirikuga liitumist.

Mõlemad on õiged [nii need, kes arvavad, et enne ristimist pole mõtet katehheesi läbi viia, sest küsimused tekivad alles pärast ristimist, kui ka nendel, kes arvavad, et enne ristimist peaks ka midagi teadma]. See on selge, et kasvamine algab alles peale ristimist, vaimne tajumine, teatud mõttes ristimine teeb ukse lahti, enne on ta kinni (40-50 a).

Tänapäeval on reegel see, et mingeid reegleid ei ole. Iga inimesega tuleb suhelda temanäoliselt. Mõne inimesega suhtled aastaid, enne kui ta üldse on nõus ristima tulema, on inimesi, kes vastupidi, peale ristimist alles avanevad, hakkavad käsnana kõike enda sisse imema, tulevad kirikusse ja muidugi saavad armulaual käima, see on ka suur asi (40-50 a).

Mõned väikestes maakohtades tegutsevad preestrid ei tegele katehheesiga seetõttu, et koguduses pole huvi selle vastu, kogudusse kuuluvad peamiselt vanemad inimesed, kes on õigeusklikest peredest ja preestritel on imelik hakata neile algseid usutõdesid selgitama, isegi kui nad möönavad, et koguduse liikmete teadlikkus kiriku õpetusest on kasin.

Mina ei tee mitte midagi [mingit katehheesi]. Pühapäevakoole ei tee. Koguduse keskmine vanus on 60 aastat, kellele ma seda pühapäevakooli teen, need on enamus vanad liikmed, traditsioonidega peredest (50-60 a).

Teist vaatenurka esindavad preestrid, kes kas on korraldanud või korraldavad süstemaatilisi usuõpetuse kursusi ja usuvad, et pikk ja põhjalik katehumeenide õpetamine on vajalik.

90-ndate algul, kui huvi oli suurem, siis minu kursus kestis 30 tundi. [See on] põhjaliku kursuse mõõt (60-70 a).

Kõik täiskasvanud ja teismelised peaksid [katehheesis käima]. Lastele me pole teinud, vanuses nii kuue ja neljateistkümne vahel [---]. Enamasti [kohtume] rohkem kui kaheksa korda, sõltub rühmast. Kui on suurem rühm, on rohkem küsimusi, mõni on vahel puudu. Õige oleks teha [---] 2-3 aastat, aga ma tajun seda meie õhkhonda, et inimesed kaoksid ära, aga need, kes jä̈̈ksid, oleksid muidugi väga pühendunud. Mina teen [katehheesi] tavaliselt pool aastat (40-50 a). 
Mõnel preestril on terve katehheesi kursus välja töötatud ja neil on mingi standard, mitu tundi tavaliselt usuõpetust antakse, see varieerub paarikuusest katehheesist kuni aasta või isegi kolmeaastase programmini välja.

See on ikka erand, kui me ristime täiskasvanut ilma süstemaatilise katehheesita. Kümme kohtumise ringi on keskmine praktika, tavaliselt jääb sinna kaheksa ringi. Peab jälgima inimese motiveeritust, peab jälgima ka kaudseid asju. Mõne inimesega jääb see kuhugi tasandile pidama, ei olegi rohkem vaja (30-40 a).

Kõigepealt vestlen inimesega, siis vaatan, mida rääkida, kas õpetada ainult ristimärki tegema või rääkida midagi enamat ka. Kahest korrast [katehheesist] kunagi ei piisa. Kõigepealt ma räägin ära, et katehhees on kolm aastat, siis kirik otsustas, et teeme kaks, ja lõpuks tuli praktika, et okei, üks aasta. Ja siis me arutame, et palju me siis sinuga teeme. Tavaliselt inimesed siis ütlevad, et teeme siis ikka aasta vähemalt. Need, keda ma siin täiskasvanuna olen ristinud, ongi käinud aasta. On kirikuaasta läbi teinud ja ülestõusmipühade eelsel päeval oleme siis ristinud, nagu kombeks on. Aasta jooksul käivad teenistustel ja katehheesis minu juures kodus. Me oleme teinud [kohtunud] kord nädalas. [---] Iga kord annan neile midagi, mis ma olen printinud, siis tuleme kokku ja ma vaatan, kas nad üldse midagi lugenud on või, siis ma saan aru, et mis me teeme, kas läheme edasi või nämmutame sellesama jälle läbi. Ma tahan, et inimesed natukenegi aru saaks, kus perekonnas nad siis hakkavad nü̈̈ elama. See on nendele endale parem ja lihtsam (50-60 a).

Mul on selline kolmeaastane programm, esimene aasta vaatame usutunnistuse põhjalikult läbi, teine aasta jumalik liturgia, siis vaatame ka need preestripalved läbi, mida kõik meie kirikus kaasa ei loe. Kolmas aasta [vaatame] pühakute elu (40-50 a).

Üldiselt ollakse konsensusel selles osas, et katehhees annab vaid minimaalsed baasteadmised, kuid õigeusklik õpib terve elu.

Ma ei muretse eriti katehumeenide või katehheesi pärast, võibolla tõesti teen ma pikalt katehheesi, aga teised teevad lühemalt, sest katehhees on eluaeg, see kestab kogu aeg ja selline kärsitus, kibelemine oli meil, endistes protestantides, väga sees. Kui ma tulin õigeusu kirikusse ja see õpetati mulle esimesena selgeks, ja see on suur tarkus, et me õpime läbi praktika. Meie oleme soomeugrilased, meie õpime folkloori suust suhu, praktikaga ja eluga ja siis saab see meie eluks. Ja kui me õpime, nagu lääne koolkonnas, natuke skolastilisemalt, ja õpime kõik need erinevad 
teoloogiavoolud ära ja piiblikriitika ja allikakriitika ja kõik muud asjad, siis me lendleme nii kõrgel, ja tegelikult ei tea me tuhkagi. Õigeusus nimetatakse teoloogiks ju seda, kes elab püha elu, mitte seda, kes on teoloogilise hariduse saanud. Rahunesin ka preestrina maha, et ei ole vaja, et inimesed saaksid kohe Halkedoni kirikukogu kirikuisade asjast kohe klõks-klõks aru. Võibolla nad ei saagi kunagi aru, kui saavad, saavad hiljem ja siis on tore (50-60 a).

\section{Katehheesi korraldamise viisid}

Peale klassikalise katehheesi, kus preester jagab usuõppijatele individuaalselt teadmisi, on ka teisi alternatiivseid usuliste teadmiste levitamise viise. Levinuim on katehheetilise kirjanduse lugeda andmine.

Mõnele preestrile ei sobi aga katehheesiga tegelemine üldse või ei pea nad seda vajalikuks ja leiavad, et teadmine tuleb inimeseni teisiti viia.

Mulle ei meeldi katehheesi teha, ma ei ole lobiseja. Kui täiskasvanud inimene tahab [kirikusse] tulla, tal on huvi, tänapäeval, kui oskad vähemalt üht võorrkeelt või midagi, siis vene keeles võid ennast surnuks lugeda. Kui huvi ei ole, mida ma siis talle ikka pajatan? Kui on küsimused, siis proovin vastata, või soovitan lugeda seda või toda. Eraldi katehheesi tundi pole ma eriti teinud, kui ma tahan midagi selgeks teha, siis see käib kuidagi teistmoodi, igapäevaselt (40-50 a).

Paljudes kohtades, kus kogudusel on ruumid, kus peale teenistust koos istuda, korraldatakse pühapäevakoole või kohviõhtuid, kus arutatakse ka usulisi küsimusi, mida võib võtta kui vabas vormis katehheesi. Korraldatakse pere- või lastelaagreid, kus toimuvad ka usuteemalised loengud ja vestlused.

[Katehhees käib] jumalateenistuse kaudu, sellesama vestlusringi kaudu, mis meil on peale liturgiat - meil on alati peale liturgiat vestlusring, tuleme siia, joome kohvi ja sööme ja räägime. Seda võibki katehheesiks pidada, alati tulevad mingid küsimused, see on katehhees kohvitassi ääres. See on meil olnud nii juba kümme aastat. [---] Ma olen pigem seda meelt, et inimene peab ise küsima, ja siis mina vastan, mitte mina ei topi talle dogmasid pähe (40-50 a).

Meil on vahelduva eduga olnud pühapäevakoole, lastele ja täiskasvanutele, sõltuvalt, kellele vaja on. Siin on palju olnud. On koguduse üritused. Ühised vastlapäevad, siis tekib õrn side kirikuga. Saadame lapsi laagritesse (30-40 a). 
Mõned preestrid (ja mitte ainult väikestes kogudustes) võtavad aja käia ka kodudes ja sel viisil usulisi teadmisi jagada.

Praegu olen läinud seda teed, et suhtlen peredega. Peredega, kus on lapsed. Usuõpetus käib läbi laste. Teen koduvisiite, neid on praegu paar-kolmkümmend. Pidev suhtlemine, see toimib (40-50 a).

Me räägime päris pikalt. Sellises stiilis [vestluse vormis]. Kõige parem teoloogiline koolitus on, kui preester on koguduse teenija, ta räägib nendega kogu aeg. Ma suhtlen inimestega, käin kodudes, võtan päeva ette ja käin hooldekodus, kodudes, räägime. Teoloogia on reaalne elu, mitte midagi eraldiseisvat (50-60 a).

Katehheetilisi jutlusi peetakse ka jumalateenistuse ajal või pärast seda. Õigeusu kirikus peetaksegi liturgiat peamiseks õppimise vormiks, teoloogiliste teadmiste omandamisel (Meyendorff 1983: 7; Schmemann 1983; Vrame 2008: 282 ja sealsed viited, eriti Constance Tarasari omad), ning see ongi suuremas osas eestikeelsetes kogudustes olulisim usuliste teadmiste saamise moodus.

Iga pühapäev, kui ma loen evangeeliumi, siis ma seda ka seletan. Kas kohe peale evangeeliumi lõpus või liturgia lõpus, või mõlemal korral. Suure paastu ajal peale õhtuteenistust ka räägin (40-50 a).

Iga teenistus algab väikese katehheesiga, igal teenistusel on väike jutlus ja iga teenistus minul lõpeb väikse katehheesiga (40-50 a).

Katehhees toimub ka pihi käigus, aga et eestikeelsete koguduseliikmete seas (eriti EAÕKs) ei ole pihil käimine kuigi levinud komme, ei saa seda pidada kuigi tähtsaks usuliste teadmiste saamise viisiks.

Kui nad [koguduse liikmed] pihil käivad, siis ka räägin [usutõdedest], aga eraldi tunnid praegu ei ole (40-50 a).

Nagu eespool öeldud, pole paljudes kogudustes ruume, kus kokku saada või on preestritel suur koormus ja nad ei jõua seda teha, kuigi möönavad selle vajalikkust.

Mul ei ole aega pühapäevakooli anda, mul on nii meeletu koormus. [---]

Mina alustasin loenguid, neid ma jõuan veel pidada [koguduse liikmetele kui ka liituda soovijatele], aga lastega pühapäevakooli ei jaksa (40-50 a).

Enamik preestritest möönis, et teistes konfessioonides on usutõdede õpetamine ja eriti noortetöö paremini korraldatud, ning paljud mõtisklevad, kuidas ka oma koguduses olukorda parandada. 


\section{Kokkuvõte}

Usuõpetus on eestikeelsetes õigeusu kogudustes korraldatud erinevalt. Enamasti vestlevad preestrid kirikuga liituda soovijatega enne nende kogudusse vastu võtmist ning püüavad välja selgitada inimeste sisemist valmisolekut kirikuga liitumiseks ning liituda soovimise motiive. Seda ei tehta alati, üksikud preestrid võtavad inimese kirikusse ka ilma temaga eelnevalt suhtlemata ja usuõpetust andmata.

Üldjuhul peetakse teatud usutõdede omandamist vajalikuks ka enne vaderiks hakkamist, selle suhtes olid vaimulikud isegi rangemad kui enda ristida laskmise puhul, sest ristivanemaks olemisega kaasneb vastutus lapse ees, kohustus olla lapsele vaimseks eeskujuks ning anda lapsele usulist kasvatust ja teadmisi. Siinkohal võib tsiteerida MPEÕK ülempreestrit Igor Prekupi, kes selle seisukoha järgmiselt kokku võtab: "Vader on ju otsekui käendaja, rääkimata sellest, et last ristitakse vanemate usu peale" (Prekup 2012: 81).

Usuõpetuse sisu ei ole ainult kuivade teadmiste omandamine, sest õigeusk ei ole skolastiline, üksnes puhta teadmise ja intellektiga pole võimalik Jumala tundmiseni jõuda. Seega keskendutakse katehheesis pigem inimese hinge harimisele, tema soovide ja mõtete suunamisele, mitte kuivade teadmiste pähe ajamisele. Isegi need preestrid, kes on seadnud katehumeenidele teatud miinimumnõuded (nt usutunnistuse peast teadmine), möönavad, et olulisem kui usutunnistuse luuletusena peast teadmine on see, et inimene saaks sügaval sisimas aru, mida ta tunnistab ja millesse usub, või vähemalt et tema soov kirikuga liituda oleks tõeline ja tuleneks sügavast sisimast, mitte pragmaatilistest põhjustest või soovist leida uusi elamusi. Enamik preestritest sooviksid ja töötavad selle nimel, et inimestel oleksid vähemalt elementaarsed teadmised õigeusu teoloogiast ja traditsioonist, kuid samas ollakse ka pragmaatilised ja saadakse aru, et tänapäeva inimene on isekas ja pinnapealne ja pikk katehhees peletaks inimesed kirikust sootuks minema. Üksmeelel ollakse selles, et õigeusklik õpib kogu elu ning katehhees enne kirikuga liitumist ei peaks jääma ainsaks usutõdede omandamise ajaks.

Usuõpetuse andmise viisid on erinevad, alates lihtsast vestlusest, kirjanduse soovitamisest, teenistuse ajal katehheetiliste jutluste pidamisest, ning lõpetades ühiste ürituste korraldamisega, katehheetilise kirjanduse välja andmisega, pühapäevakoolide korraldamise ja kodude külastamisega. Peamine katehheetiline sõnum jõuab inimeseni jumalateenistuse kaudu, seda nii teenistuse käiku jälgides teenistuses kasutatavate tekstide vahendusel kui ka teenistuse ajal või enne/pärast seda peetavate lühikeste jutluste abil. 
Mõnel preestril on välja töötatud loengute programm katehumeenidele. Kursuste pikkus jääb keskmiselt paari-kolme kuu piiresse (8-10 kohtumist), kuid korraldatakse ka pikemaid kursusi. Enamasti peetakse kirikuga liitumise eeltingimuseks usutunnistuse tundmist, aga ka sellesse suhtutakse vastavalt olukorrale. Olulisemaks kui usutõdede või tekstide peast teadmist peetakse inimese sisemist soovi ja valmidust kirikuga liitumiseks.

Vaatamata sellele, et kiriku(te) juhtkon(na)d peavad katehheesi väga oluliseks ning MPEÕKs on see lausa kohustuslik, napib kirikutel ressursse ning oskusi selle nõude (EAÕK puhul soovituse) täitmiseks. Nagu sedastavad Irina Pärt ja Toomas Schvak: "Vene Õigeusu Kiriku praegusaja põhiprobleem Eestis on siiski ressursside nappus. Puudu on nii inimesi kui ka raha, mida oleks vaja aktiivse katehheesi ja haridustöö tegemiseks. Koguduse preestrid on sageli üle koormatud ning kiriku ilmikliikmetel pole vajalikku väljaõpet" (Paert \& Schvak 2015: 187). Seda saab üldistada ka EAÕK kohta, kus samuti napib ressursse, kuigi nii kiriku juhtkond kui ka vaimulikud oma kogudustega pingutavad, et olukorda parandada. Eestikeelset õigeusu kirjandust on viimastel aastatel piisavalt välja antud, et anda katehumeenidele esmast infot õigeusu kohta, seevastu võib probleemiks saada pigem mõnede preestrite soovimatus katehheesi läbi viia või oskuste ja vajalike isiksuseomaduste puudumine selleks tööks. MPEÕKs tundub probleemiks olevat ka eestikeelsete katehheesivõimaluste vähesus või vähene info selle kättesaadavuse kohta.

\section{Kommentaarid}

1 Uurimistööd on toetanud Eesti Vabariigi Haridus- ja Teadusministeerium (sihtfinantseeritav teadusteema SF0180026s11) ja Euroopa Liit Euroopa Regionaalarengu Fondi kaudu (Kultuuriteooria Tippkeskus).

2 Siinkohal teen vahet katehheesil ja koolis antaval usuõpetusel. Praktilise teoloogia alla kuuluva katehheetika all peetakse silmas kirikus/kogudustes antavat usulist kasvatust ja õpetamist (vt nt teoloogiliste akadeemiate õppekavad), mis on erinev koolis antavast usuõpetusest ning mida antud artikli raames ei käsitleta. Nende kahe hariduse andmise viisi eraldi käsitlemisest vt nt Ališauksiene 2013: 215.

3 Ilmselt eeldab autor, et lapsed saavad koolis kas usuõpetust või kuulevad nad nendest teemadest muude õppeainete raames.

4 See üldistus on tehtud kogu maailma õigeusu kirikute kohta.

5 Õigeusu õppetooli loomisest vt Schvak 2011: 72-75.

6 VÕKi seisukohti vt nt Stoeckl 2014: 83.

7 Venemaa Õigeusu Kiriku (VÕKi) kodulehekülg: http://www.patriarchia.ru/db/ text/1663546.html (13. mai 2016). 
8 MPEÕK põhikiri http://www.orthodox.ee/official-docs_est.html (13. mai 2016), EAÕK põhikiri http://www.eoc.ee/eesti-apostlik-oigeusu-kirik/eesti-apostlik-oigeusu-kirikupohikiri/ (13. mai 2016).

9 http://haridus.ekn.ee/lastetoo-1-4-lastetoo-ja-puhapaevakoolid-tanapaeval/\#Eesti_ Apostlik-Oigeusu_Kirik (13. mai 2016).

${ }^{10}$ Vaatamata sellele, et ka MPEÕK on EKNi liikmeskirik, ei leia nende käsitlust selle teema kohta EKNi koduleheküljelt.

${ }^{11}$ EAÕK kodulehekülg www.eoc.ee (13. mai 2016).

12 http://www.eoc.ee/mteropoolia/ (13. mai 2016).

${ }^{13}$ Autori avaldamata andmed.

${ }^{14}$ MPEÕK selgitav sõnaraamat http://www.orthodox.ee/orthodic/10_k/katehizatsia.html (16. mai 2016).

$15 \mathrm{http}: / /$ www.pravoslavie.ee/ (16. mai 2016).

16 http://www.pravoslavie.ee/Table/Воскресные-школы/ (16. mai 2016).

${ }^{17}$ Küsimuse sõnastus: "Kuidas konkreetselt teie teoloogilist haridust jagate? Kuidas seda üldiselt koguduses tehakse, milline on katehheesi korraldus?"

${ }^{18}$ Õigeusu kirik üldjuhul ei nõua teistest kristlikest kirikutest üle tulemise puhul üle ristimist ja piirduvad salvimisega (konfirmatsioon), aga sellest on erandeid, nt Pühtitsa klooster ristib ümber ka kristlasi, sh EAÕK või muude õigeusu kirikute liikmeid. Pühtitsas enne ristimist katehheesi ei toimu.

\section{Kirjandus}

Ališauksiene, Milda 2013. Religious education in Lithuania. Davis, Derek \& Miroshnikova, Elena (toim). The Routledge International Handbook of Religious Education. London \& New York: Routledge, Taylor and Francis Group, lk 212-216.

Kalender 2013 = Õigeusu kiriku kalender 2014. Tallinn: Eesti Apostlik-Õigeusu Kirik.

Kooviste, Helen 2011. Nü̈̈disaja usuõpetustöö EAÕK kogudustes. Magistritöö. Tallinn: EELK UI.

Kozhuharov, Valentin 2006. Towards an Orthodox Christian Theology of Mission. Veliko Tarnovo: Vesta Printing House.

McDowell, Maria Gwyn 2014. Catechumens. McGuckin, John Anthony (toim). The Concise Encyclopedia of Orthodox Christianity. Chichester (UK): Wiley, Blackwell, lk 88.

Meyendorff, John 1983. Byzantine Theology. Historical Trends and Doctrinal Themes. New York: Fordham University Press.

Paert, Irina \& Schvak, Toomas 2015. Haridus ja õigeusu kirik Eestis. Eek, Liina (toim). Mitut usku Eesti IV. Valik usundiloolisi uurimusi: õigeusu eri. Tartu: Tartu Ülikooli kirjastus, lk 171-192. 
Prekup, Igor 2012. Õigeusklikud - kes nad on? Jõks, Eerik (toim). Astu alla rahva hulka. Artikleid ja arutlusi Eesti elanikkonna vaimulaadist. Tallinn: Eesti Kirikute Nõukogu, lk 78-89.

Schmemann, Alexander 1983. Liturgy and Life: Lectures and Essays on Christian Development Through Liturgical Experience. Syosset, New York: Orthodox Church in America Department of Christian Education.

Schvak, Toomas 2011. Õigeusu vaimulikkonna ettevalmistamisest 1918-1940. Usuteaduslik Ajakiri, lk 70-86 (http://usuteadus.ee/wordpress/wp-content/uploads/2011\%20 \%2862\%29/Schvak.pdf - 17. mai 2016).

Stefanus, metropoliit 2011. Pilguheit õigeusku. Ajalugu ja teoloogia. Tallinn: EAÕK kirjastus.

Stefanus, metropoliit 2013. ...ja Jumal nägi, et nii on hea! Usk ja Elu 11, lk 55-62 (http:// www.eoc.ee/wp-content/uploads/2014/02/2013-uskelu_11.pdf - 17. mai 2016).

Stefanus, metropoliit 2015. Tallinna ja kogu Eesti metropoliit Stefanuse kõne EAÕK 2015. a täiskogul. Metropoolia 72, lk 3-5. (http://www.eoc.ee/wp-content/uploads/2013/06/ Metropoolia_72.pdf - 18. mai 2016).

Stoeckl, Kristina 2014. The Russian Orthodox Church and Human Rights. London and New York: Routledge.

Tölpt, Aabraham 2015. Kiriku noortetöö visioon. Metropoolia 72, lk 9. (http://www.eoc. ee/wp-content/uploads/2013/06/Metropoolia_72.pdf - 18. mai 2016).

UE $1917=$ [Autorita.] Piiskopkonna koosolekult. Usk ja Elu 87-89, lk 343-344.

UE 1919 = [Autorita.] Eestimaa apostliku õigeusu koguduse täiskogu koosolekul 21. märtsil 1919 vastu võetud resolutsioonid kiriku valitsemise küsimuste kohta. Uus Elu 3, lk 44-46.

Vrame, Anton C. 2008. An Overview of Orthodox Christian Religious Education. De Souza, Marian \& Durka, Gloria \& Engebretson, Kathleen \& Jackson, Robert \& McGrady, Andrew (toim). International Handbook of the Religious, Moral and Spiritual Dimensions in Education. Springer, lk 277-294.

Wallace L. Daniel 2006. The Orthodox Church and Civil Society in Russia. College Station: Texas A\&M University Press.

Ware, Kallistos 2001. Õigeusu tee. Tallinn: EAÕK kirjastustoimkond. 


\section{Internetiallikad}

(viimati külastatud 13. juuni 2016)

EAÕK kodulehekülg www.eoc.ee, http://www.eoc.ee/metropoolia/

EAÕK põhikiri http://www.eoc.ee/eesti-apostlik-oigeusu-kirik/eesti-apostlik-oigeusukiriku-pohikiri/

EKNi kodulehekülje lastetöö osa http://haridus.ekn.ee/lastetoo-1-4-lastetoo-japuhapaevakoolid-tanapaeval/\#Eesti_Apostlik-Oigeusu_Kirik

MPEÕK kodulehekülje pühapäevakoole tutvustav osa http://www.pravoslavie.ee/Table/ Воскресные-школы/

MPEÕK põhikiri http://www.orthodox.ee/ustav_est.html

MPEÕK selgitav sõnaraamat http://www.orthodox.ee/orthodic/10_k/katehizatsia.html

Venemaa Õigeusu Kiriku (VÕKi) kodulehekülg http://www.patriarchia.ru/db/ text/1663546.html

\section{Summary}

\section{Catechesis in Estonian Orthodox Church}

\section{Liina Eek}

Keywords: catechesis, Estonian Apostolic Orthodox Church, Estonian Orthodox Church of Moscow Patriarchate, Orthodox theology

The article describes how catechesis is given to Estonian-speaking people in two Estonian Orthodox churches - the Estonian Apostolic Orthodox Church (EAOC) and the Estonian Orthodox Church of Moscow Patriarchate (EOCMP). An overview is also given of the opinions of Orthodox priests about the necessity of catechesis in parishes, which is deemed to be the minimum needed knowledge about Orthodox theology for being a church member, and about when the catechesis should be given (before baptism/ confirmation, after that, or throughout life).

Catechesis in Orthodox church is usually given before joining the church and its length, content, and methodology vary, being dependent on resources in the parish (rooms, people, etc.), on priests' knowledge, ability, and skills to give catechesis, and finally on the interest of congregation members. Catechesis before joining the church is not obligatory in the EAOC, even though it is encouraged and its importance is stressed by the metropolitan. In the EOCMP, catechesis before joining the church is obligatory, and its length is at least a couple of meetings with the priest. The article describes how different priests solve the problem of giving catechesis.

The article is based on original empirical data collected during a religious-sociological study, undertaken in 2012-2014, when 57 interviews were carried out with Estonian- 
speaking clergy and lay members of both Estonian Orthodox churches. Based on interviews with 18 priests, the article highlights the bottlenecks of Estonian Orthodox catechesis: churches do not have enough resources and skilled clergy for giving active catechesis in parishes, but both churches and their clergy make efforts to improve the situation. There is enough catechetic material available in Estonian, yet the problem is rather the lack of skills or willingness of some priests to give catechesis. In the EOCMP the problem could also be lack of publication opportunities or availability of information about catechetic materials in Estonian. 